\title{
Adversity Quotient (Aq) Ditinjau dari Jenis Kelamin Siswa Kelas VI SD
}

\section{Putu Nanik Siska Sri Agustina ${ }^{1 *}$, Ni Wayan Suniasih²}

12 Prodi Pendidikan Guru Sekolah Dasar, Universitas Pendidikan Ganesha, Singaraja, Indonesia *e-mail: putunaniksiskasriagustina17@undiksha.ac.id

\begin{abstract}
Abstrak
Perbedaan yang dimiliki oleh siswa laki-laki dan perempuan menyebabkan dalam menghadapi suatu permasalahan pembelajaran memiliki cara berbeda-beda. Pembelajaran yang sulit disekolah sering membuat siswa putus asa dan mudah menyerah. Hal ini dikarenakan masih rendahnya ketahanan siswa dalam menghadapi suatu permasalahan dalam pembelajaran. Ketahanan seseorang dalam menghadapi permasalahan dikenal dengan Adversity Quotient (AQ). Penelitian ini bertujuan untuk menganalisis perbedaan yang signifikan $A Q$ antara siswa laki-laki dan perempuan sebagai informasi yang berkaitan dengan ketahanan yang dimiliki oleh masing-masing siswa dalam menghadapi suatu permasalahan dalam proses pembelajaran. Penelitian ini merupakan penelitian ex post facto jenis kausal komparatif dengan metode pengumpulan data diperoleh melalui angket tertutup. Sebelum data dianalisis dilakukan uji normalitas menggunakan chi kuadrat dan uji homogenitas menggunakan uji fisher sebagai prasyarat dilakukan analisis uji-t. Berdasarkan hasil perhitungan analisis uji-t diperoleh t hitung $=2,41$ pada taraf signifikan $5 \%$ dan $(\mathrm{db}) 55+55-2=$ 108 diperoleh $t$ tabel $=1,98$. Sehingga nilai $t$ hitung $=2,41>t$ tabel $=1,98$, dengan demikian dapat disimpulkan bahwa $A Q$ yang dimiliki siswa laki-laki dan perempuan berbeda secara signifikan dan terimplikasi sebagai tambahan informasi mengenai pengembangan $A Q$ untuk siswa sehingga membantu memberikan dampak positif terhadap hasil belajar siswa di sekolah.
\end{abstract}

Kata kunci: $A Q$, jenis kelamin, siswa sd

\begin{abstract}
The differences between male and female students lead to different ways of dealing with a learning problem. Difficult learning in school often makes students easily give up. This is due to the low resilience of students in facing a problem in learning. A person's resilience in facing problems is known as Adversity Quotient (AQ). This study aims to analyze the significant differences in $A Q$ between male and female students as information related to the resilience each student has in facing a problem in the learning process. This research is an expost facto comparative causal type with the method of collecting data obtained through a closed questionnaire. Before the data were analyzed, the normality test was carried out using the chi square test and the homogeneity test using the Fisher test as a prerequisite for the $t$-test analysis. Based on the results of $t$-test analysis calculations obtained $t$-count $=2.41$ at a significant level of $5 \%$ and $(\mathrm{db}) 55+55-2=108$ obtained $t$-table $=1.98$. So that the value of $t$ count $=2.41>t$-table $=1.98$, thus it can be concluded that the $A Q$ of male and female students is significantly different and implied as additional information about the development of $A Q$ for students so that it helps to have a positive impact on the results of student learning in school.
\end{abstract}

Keywords: $A Q$, gender, elementary school students

\footnotetext{
${ }^{*}$ Corresponding author.

Received 30 Januari 2021; Accepted 1 Maret 2021; Available online 8 April 2021 (C) 2021 MI All Rights Reserved
} 


\section{Pendahuluan}

Pendidikan merupakan salah satu cara untuk mengembangkan sumber daya manusia menjadi lebih baik sesuai dengan harapan bangsa dan negara Indonesia. Pendidikan diartikan pula sebagai hal pokok penopang kemajuan bangsa (Fitriyadi, 2013; Kadi \& Awwaliyah, 2017). Siswa merupakan cerminan kualitas pendidikan (Sibuea \& Andy, 2017). Sedangkan guru merupakan aktor utama dalam pelaksanaan proses pembelajaran sebagai fasilitator, mediator, pengelola maupun pengajar untuk membantu siswa mewujudkan apa yang diharapkan oleh bangsa dan negara Indonesia (Idzhar, 2016). Perasaan yang dimiliki oleh siswa tidak selalu senang, aman ataupun nyaman dalam proses pembelajaran yang dilaksanakan disekolah. Kesenjangan yang terjadi khususnya di sekolah dasar yakni beberapa siswa merasa sekolah merupakan tempat yang sangat membosankan, menakutkan, hanya untuk membuang-buang waktu, dan menyusahkan diri sendiri. Hal tersebut disebabkan karena terdapat beberapa siswa yang merasa kurang percaya diri dan takut gagal (Darmadi, 2015; Putra, 2016).

Permasalahan yang terjadi saat ini yaitu siswa merasa tingkat intelektual yang dimiliki lebih tinggi dibandingkan temannya, namun nilai ulangan yang didapatkan selalu lebih rendah. Ini menimbulkan gejolak dalam diri siswa berpersepsi bahwa kecerdasan saat ini belum tentu menjamin kesuksesan. Sukses dan gagal merupakan sesuatu yang tidak dapat dipisahkan satu sama lain (Manurung, 2021). Walaupun sebenarnya kebanyakan individu beranggapan bahwa kegagalan adalah sesuatu hal yang membuat dirinya menjadi jatuh dan di bawah. Selain itu terjadinya kesenjangan antara harapan tinggi yang dimiliki siswa namun tidak berbuah hasil baik menyebabkan tingkat kebosanan siswa belajar serta hilangnya semangat siswa dalam belajar menimbulkan rendahnya hasil belajar siswa (Jayantika, 2018; Ristiana, 2020). Permasalahan tersebut sama halnya dengan hasil wawancara yang dilaksanakan di SD Gugus 1 Blahbatuh Gianyar dilihat bahwa masih banyak terdapat siswa mudah menyerah sebelum ujian dimulai karena nilai ujian didapatkan selalu rendah, siswa merasa sekolah merupakan tempat yang sangat membosankan, siswa putus asa dalam pembelajaran jika terdapat pembelajaran yang sulit serta siswa sangat mudah sakit hati dan tidak percaya diri jika diberikan komentar negatif oleh guru. Selain itu, siswa belum mampu mengatur dan mengarahkan dirinya bila mendapatkan pembelajaran yang sulit, selalu merasa tidak yakin dan tidak mungkin berhasil mengerjakan tugas, sangat mudah sakit hati dan hilang percaya diri, menyerah sebelum ujian dimulai, merasa takut dan tidak punya ide. Serta dilihat dari permasalahan yang ditinjau dari jenis kelamin, siswa perempuan lebih bersemangat dalam menjalani pembelajaran dibandingkan siswa laki-laki, siswa perempuan lebih bersemangat jika dipuji dibandingkan siswa laki-laki namun siswa laki-laki lebih tenang dalam menghadapi suatu permasalahan dibandingkan perempuan.

Darwin (2019) berpendapat sebuah kalimat yaitu Survival of The Fittest, fittest yang berarti mampu beradaptasi terhadap lingkungan sedangkan survival berarti bukan masalah yang paling pintar namun yang paling adaptif. Adaptif ini mengandung arti mampu bertahan sehingga mudah menyesuaikan diri terhadap keadaan. Jika seseorang hanya memiliki IQ yang tinggi dan tidak memiliki ketahanan dalam dirinya untuk menghadapi suatu permasalahan, maka untuk meraih kesuksesan itu niscaya sulit. Hal ini dikarenakan untuk meraih pengetahuan yang menjadi kesuksesan, seseorang harus memiliki IQ yang tinggi dan mempunyai AQ karena keduanya sangat berperan (Hidayat, Herdiman, Aripin, Yuliani, \& Maya, 2018; Stoltz 2007). Hal ini sejalan dengan penelitian yang dilakukan oleh Baharun \& Adhimah (2017) yang menyatakan faktor lain yang menentukan kesuksesan selain harus memiliki IQ adalah kemampuan yang kuat terhadap kesulitan hidup seseorang yang disebut dengan Adversity Quotient (AQ) atau ketahanmalangan.

Adversity diartikan sebagai suatu kemalangan atau kesengsaraan sedangkan Quotient diartikan sebagai kemampuan atau kecerdasan (Novilita \& Suharnan, 2013; Suhendri, 2018). Jadi jika dikaitkan dengan Adversity Quotient berarti kemampuan seseorang dalam menghadapi kemalangan. $A Q$ atau juga disebut dengan ketahanmalangan merupakan kemampuan seseorang dalam mengamati serta mengolah kecerdasan yang 
dimiliki menjadi tantangan yang dapat diselesaikan (Kauniyah, 2016; Stoltz, 2000). Sedangkan menurut $\mathrm{AQ}$ merupakan daya tahan atau ketahanan seseorang menghadapi permasalahan. Maka dari pendapat tersebut dapat disimpulkan $A Q$ merupakan kecerdasan seseorang dalam bertahan menghadapi permasalahan dan menjadikan permasalahan tersebut sebagai tantangan yang mampu diselesaikan.

$A Q$ yang dimiliki dalam diri siswa menjadikan siswa tersebut lebih kuat dalam mengatasi segala rintangan yang didapatkan dalam proses pembelajaran (Fadhilah, 2020). Sukses dan gagal merupakan akhir dari rangkaian panjang maka terlepas dari hal tersebut apakah perjalanan itu efektif atau tidak, apakah berdasarkan visi misi yang jelas, apakah perjalanan itu berbekal kesabaran atau tidak, ataupun apakah perjalanan itu disertai daya juang atau tidak (Hidayat \& Sariningsih, 2018). Dari penjelasan secara kompleks mengenai $A Q, A Q$ dinilai sangat berpengaruh terhadap kehidupan khususnya dalam pendidikan mengatasi permasalahan-permasalahan yang dialami siswa tersebut. Setiap orang memiliki $A Q$ namun $A Q$ yang dimiliki berbeda-beda tergantung tingkat kemampuan atau daya tahan yang seseorang miliki (Irfan, 2018; Yoga, 2016). Sebagai seorang siswa tentunya AQ yang dimiliki berpengaruh terhadap proses pembelajaran dikelas. Semakin tinggi $A Q$ yang dimiliki, siswa semakin berpengaruh positif terhadap hasil belajar siswa.

Penelitian yang dilakukan oleh Leonard \& Amanah (2014) menyatakan semakin baik AQ yang dimiliki siswa semakin baik hasil belajar matematika yang didapatkan. Sejalan dengan itu Hidayat et al., (2018) menyatakan AQ memberikan pengaruh yang positif terhadap pencapaian kemampuan penalaran kreatif matematis mahasiswa calon guru, dengan besarnya pengaruh $60,9 \%$ sedangkan sisanya $(39,1 \%)$ dipengaruhi oleh faktor lain di luar $A Q$. Sehubung $A Q$ merupakan faktor yang berpengaruh positif terhadap hasil belajar siswa maka $A Q$ yang dimiliki oleh siswa perlu diperhatikan untuk mengatasi kesenjangankesenjangan yang berhubungan tentang ketahanan dalam menghadapi suatu permasalahan. Dilihat dari $\mathrm{AQ}$ dipengaruhi oleh berbagai faktor, siswa disekolah dasar memiliki berbagai perbedaan. Perbedaan yang dimiliki oleh siswa disekolah menyebabkan guru hendaknya mampu menyeimbangi hal tersebut (Parantika, 2020). Perbedaan yang dimiliki oleh siswa salah satunya yaitu jenis kelamin.

Jenis kelamin merupakan sebutan untuk membedakan antara laki-laki dan perempuan. Jenis kelamin merujuk pada teori sex untuk membedakan laki-laki dan perempuan secara bidologis sejak individu lahir (Amory, 2019; Santrock, 2009). Jenis kelamin sering dikaitan dengan prilaku maskulin dan feminim, instilah bagi laki-laki sedangkan feminim merupakan istilah bagi perempuan (Artaria, 2016). Jenis kelamin memiliki perbedaan ciri khas masing-masing secara jelas dapat dilihat seperti cara berpakaian, tata rambut, maupun aksesoris yang digenakan. Laki-laki dan perempuan berlatar belakang yang berbeda dilihat dari prilaku dan kebiasaan-kebiasaan yang dilakukan (Santrock, 2009; Firmanti, 2017). Namun, Artaria (2016) secara teoritis laki-laki dan perempuan memiliki perbedaan fisik, biologis, dan psikologis. Selain itu, laki-laki dan perempuan dari segi kognitif memiliki perbedaan (Santrock, 2009). Perbedaan yang dimiliki yaitu laki-laki diukur secara kognitif laki-laki lebih cerdas mengenai keterampilan dan visiopasial dibandingkan perempuan. Sedangkan perempuan lebih cerdas kemampuan verbal dibanding laki-laki. Ditinjau dari cara berfikir antara siswa laki-laki dan perempuan dalam memecahkan masalah matematika, siswa laki-laki mampu menangani masalah spesifik sedangkan perempuan menangani masalah secara logistik (Nur \& Palabo, 2018).

Sejalan dengan itu perbedaan jenis kelamin sangat berpengaruh terhadap keterampilan siswa dalam berfikir kritis dan berargumentasi (Farida, 2018). Serta dalam mengerjakan tugas dalam pembelajaran siswa laki-laki maupun perempuan memiliki cara menyelesaikan dengan berbeda pula (Parantika, 2020). Dari perbedaan-perbedaan yang dimiliki oleh laki-laki dan perempuan menjadi sebuah tantangan dalam menjalankan pembelajaran yang bertentangan dengan keunggulan kecerdasan siswa baik antara laki-laki maupun perempuan serta cara untuk menghadapi dan menyelesaikan tugas berbeda pula. Tidak terlepas dari ketahanan siswa dalam mengatasi permasalahan dalam pembelajaran, laki-laki dan perempuan tentunya memiliki perbedaan dalam mengatasinya. Pentingnya 
penelitian dilaksanakan sebagai seorang guru mesti dapat memahami masing-masing karakteristik siswa, kelebihan dan kekurangan yang dimiliki siswa maupun kebutuhan serta kendala-kendala siswa dalam proses pembelajaran. Sehingga penelitian AQ yang ditinjau dari jenis kelamin siswa sangat penting untuk dilaksanakan. Penelitian yang dilakukan oleh MZ, Risnawati, Kurniati, \& Prahmana, (2017) mengenai AQ yang ditinjau dari jenis kelamin menyatakan bahwa $A Q$ antara laki-laki dan perempuan berpengaruh terhadap jenis kelamin dibuktikan secara deskriptif $A Q$ laki-laki dan perempuan berbeda dengan perolehan ratarata $A Q$ laki-laki yaitu 159,39 sedangkan rata-rata $A Q$ perempuan yaitu 98,89.

Penelitian ini bertujuan untuk menganalisis perbedaan yang signifikan $A Q$ antara siswa laki-laki dan perempuan sebagai informasi yang berkaitan dengan ketahanan yang dimiliki oleh masing-masing siswa dalam menghadapi suatu permasalahan dalam proses pembelajaran. Maka dari itu pentingnya penelitian mengenai $A Q$ yang ditinjau dari jenis kelamin mengingat berdasarkan teori maupun penelitian sebelumnya membuktikan bahwa jenis kelamin berpengaruh terhadap $A Q$ yang miliki siswa namun penelitian ini mengulas mengenai perbedaan $A Q$ yang dimiliki antara siswa laki-laki dan perempuan khususnya pada jenjang sekolah dasar.

\section{Metode}

Penelitian ini pada dasarnya untuk mengetahui perbedaan yang signifikan $A Q$ antara siswa laki-laki dan perempuan kelas VI SD Gugus 1 Blahbatuh Gianyar Tahun Ajaran 2020/2021 dengan populasi yang terdiri terdiri dari 6 sekolah diantaranya SD Negeri 1 Blahbatuh, SD Negeri 2 Blahbatuh, SD Negeri 3 Blahbatuh, SD Negeri 4 Blahbatuh, SD Negeri 5 Blahbatuh, dan SD Negeri 6 Blahbatuh. Perolehan sampel dari jumlah populasi sebanyak 110 responden dengan menggunakan teknik pengambilan sampel yaitu teknik proposional random sampling. Teknik proposional random sampling merupakan pengambilan data sampel diperoleh secara proporsional yaitu masing-masing kelas telah ditentukan dengan menggunakan rumus (Evaliana, 2015). Penentuan sampel dilihat dari tabel Issac and Michel dengan tarif kesalahan 5\%.

Penelitian yang dilakukan tanpa memberikan perlakuan atau memanipulasi variabel bebas untuk memperoleh data ataupun informasi yang diinginkan. Maka dari itu, penelitian ini digolongkan kedalam penelitian ex post facto jenis kausal komparatif. Hubungan antar variabel dalam penelitian kausal komparatif dilambangkan dengan huruf $X$ yang menandakan variabel bebas yaitu jenis kelamin siswa berperan sebagai variabel nominal yaitu siswa laki-laki dan perempuan. Sedangkan variabel terikat yaitu $A Q$ dilambangkan dengan huruf $Y$. Hal ini dikarenakan jenis kelamin siswa laki-laki dan perempuan sebagai variabel bebas timbul terlebih dahulu dibandingkan dengan $A Q$. Untuk lebih jelasnya hubungan antar variabel dalam penelitian kausal komparatif dijelaskan dengan konstalasi yang dijabarkan pada tabel 1.

Tabel 1. Desain Dasar Penelitian Kausal Komparatif

\begin{tabular}{lc}
\hline \multicolumn{1}{c}{ Jenis Kelamin (X) } & Adversity Quotient (AQ) \\
\hline Siswa laki-laki (a) & $\mathrm{X}_{\mathrm{a}} \mathrm{Y}$ \\
Siswa perempuan (b) & $\mathrm{X}_{\mathrm{b}} \mathrm{Y}$ \\
\hline
\end{tabular}

Penelitian ini digolongkan kedalam penelitian kuantitatif. Data penelitian diperoleh melalui penyebaran angket. Penskoran yang digunakan dalam angket menggunakan skala likert. Skala likert yang digunakan yaitu skala likert yang telah dimodifikasi dengan empat alternativ jawaban diantaranya sangat setuju (SS), setuju (S), tidak setuju (TS), dan sangat tidak setuju (STS) (Sukardi, 2008).

Angket dengan 32 butir pernyataan disebar kepada 110 responden yaitu 55 siswa laki-laki dan 55 siswa perempuan dengan telah melalui pengujian instrumen angket yaitu validitas teoritis dan validitas empiris. Dalam hal ini angket yang baik jika memenuhi dua 
prasyarat yaitu validitas dan reliabilitas. Validitas instrumen mengukur sejauh mana instrumen yang diukur tepat sedangkan reliabilitas mengukur sejauh mana instrumen yang dibuat dipercaya memiliki keajegan (Yusup, 2018).

Analisis data yang digunakan setelah data diperoleh yaitu menggunakan analisis statistik deskriptif dan statistik inferensial. Statistik inferensial yang digunakan yaitu pengujian hipotesis dengan uji-t. Sebelum melakukan uji-t terdapat prasyarat yaitu uji normalitas dan uji homogenitas. Uji normalitas digunakan untuk mengetahui apakah frekuensi data berdistribus normal atau tidak. Pengujian normalitas dilakukan dengan menggunakan formula chi kuadrat dengan tarif signifikansi 5\% dan derajat kebebasan (dk)= k-1. Kemudian dilakukan pengujian homogenitas guna untuk menunjukan bahwa perbedaan benar terjadi antar varians kelompok. Pengujian homogenitas dilakukan menggunakan uji fisher pada taraf signifikansi $5 \%$ dengan derajat kebebasan (dk) pembilang $n_{1}-1$ dan derajat kebebasan (dk) penyebut $\mathrm{n}_{2}-2$. Analisis uji-t dilakukan setelah data sudah melalui dua prasyarat yaitu data berdistribusi normal dan varians yang diperoleh homogen. Kriteria pengukuran analisis uji-t digunakan yaitu apabila $t_{\text {hitung }}>t_{\text {tabel }}$ dengan taraf signifikansi $5 \%$ dan $(\mathrm{db})=\mathrm{n}_{1}+\mathrm{n}_{2}-2$ maka data yang diperoleh memiliki perbedaan yang signifikan.

\section{Hasil dan Pembahasan}

Berdasarkan hasil analisis statistik deskriptif diperoleh skor tertinggi siswa laki-laki yaitu sebesar 125 sedangkan skor tertinggi siswa perempuan yaitu 126. Perolehan skor terendah siswa laki-laki sebesar 63 sedangkan skor terendah siswa perempuan sebesar 85 . Standar deviasi antara siswa laki-laki dan perempuan yaitu 18. Skor rata-rata $A Q$ siswa lakilaki sebesar 96,16 sedangkan rata-rata $A Q$ siswa perempuan sebesar 101,8. Perolehan data deskriptif siswa laki-laki dan perempuan ditampilkan pada Tabel 2.

Tabel 2. Perolehan data deskriptif siswa laki-laki dan perempuan

\begin{tabular}{lllll}
\hline Sampel & Skor Tertinggi & Skor Terendah & Standar Deviasi & Rata-rata \\
\hline Siswa Laki-Laki & 125 & 63 & 18 & 96,16 \\
$\begin{array}{l}\text { Siswa } \\
\text { Perempuan }\end{array}$ & 126 & 85 & 18 & 101,8 \\
\hline
\end{tabular}

Untuk kategori $A Q$ antara siswa laki-laki dan perempuan digunakan skala lima teoritik dengan skor rata-rata $A Q$ siswa laki-laki sebesar 96,16 dikategorikan $A Q$ yang dimiliki yaitu tegolong tinggi. Sedangkan skor rata-rata $A Q$ siswa perempuan sebesar 101,8 dikategorikan $A Q$ yang dimiliki tegolong tinggi. Berikut kategori skor skala lima $A Q$ siswa laki-laki dan perempuan ditampilkan pada Tabel 3.

Tabel 3. Kategori skor skala lima $A Q$ siswa laki-laki dan perempuan

\begin{tabular}{lll}
\hline Rentang & Hasil & Kategori \\
\hline$M i+1,5 S D i-M i+3,0 S D i$ & $104-128$ & Sangat tinggi \\
$M i+0,5 S D i-M i+1,5 S D i$ & $88-104$ & Tinggi \\
$M i-0,5 S D i-M i+0,5 S D i$ & $80-88$ & Sedang \\
$M i-1,5 S D i-M i-0,5 S D i$ & $56-72$ & Rendah \\
$M i-3,0 S D i-M i-1,5 S D i$ & $32-56$ & Sangat rendah \\
\hline
\end{tabular}

Diperoleh rata-rata $A Q$ siswa laki-laki sebesar 96,16 maka dapat dikategorikan bahwa $A Q$ siswa laki-laki digolongkan pada rentang 88 - 104 dengan kategori tinggi. Sedangkan rata-rata $A Q$ siswa perempuan sebesar 101,8 maka dikategorikan bahwa $A Q$ siswa perempuan digolongkan pada rentang 88 - 104 dengan kategori tinggi. Berdasarkan hasil analisis menggunakan statistik deskriptif dengan skala lima teoritik didapatkan bahwa AQ siswa laki-laki maupun perempuan kelas VI SD Gugus 1 Blahbatuh Gianyar Tahun 
Ajaran 2020/2021 keduanya termasuk kedalam AQ kategori tinggi namun rata-rata yang diperoleh berbeda.

Hasil analisis data selanjutnya menggunakan statistik inferensial. Statistik inferensial yang digunakan yaitu analisis uji-t namun sebelum melakukan analisis uji-t terdapat dua prasyarat yaitu uji normalitas dan homogenitas. Perolehan hasil uji normalitas $A Q$ siswa lakilaki dan perempuan kelas VI SD Gugus 1 Blahbatuh Gianyar Tahun Ajaran 2020/2021 yaitu jika $x^{2}{ }_{\text {hitung }} \leq \mathrm{x}^{2}$ tabel pada tarif signifikansi $5 \%(\mathrm{dk})=6-1=5$ berarti sebaran data berdistribusi normal. Berdasarkan hasil analisis uji normalitas diperoleh hasil $x^{2}$ hitung laki-laki $=3,93$ serta hasil $x^{2}$ hitung perempuan $=2,84$ pada tarif signifikansi $5 \%(\mathrm{dk})=6-1=5$ yaitu $\mathrm{x}^{2}{ }_{\text {tabel }}=11,07$. Sehingga dapat disimpulkan bahwa $A Q$ siswa laki-laki yaitu $x^{2}$ hitung $=3,93<x^{2}$ tabel $=11,07$ data yang diperoleh dinyatakan berdistribusi normal serta $A Q$ siswa perempuan bila dijabarkan $x^{2}$ hitung $=2,84<x^{2}$ tabel $=11,07$ data yang diperoleh dinyatakan berdistribusi normal. Uji normalitas sebaran data secara lebih jelasnya ditampilkan pada Tabel 4.

Tabel 4. Perhitungan Uji Normalitas Sebaran Data

\begin{tabular}{llll}
\hline Sampel & $\mathbf{X}^{\mathbf{2}}$ hitung & Nilai $\mathbf{x}^{\mathbf{2}}$ tabel & Keterangan \\
\hline Siswa Laki-laki & 3,93 & 11,07 & Berdistribusi Normal \\
Siswa Perempuan & 2,84 & 11,07 & Berdistribusi Normal \\
\hline
\end{tabular}

Dilanjutkan melakukan uji homogenitas sebaran data siswa laki-laki dan perempuan kelas VI SD Gugus 1 Blahbatuh Gianyar Tahun Ajaran 2020/2021 jika nilai $F_{\text {hitung }} \leq$ nilai $F_{\text {tabel }}$ pada taraf signifikansi 5\%, (dk) pembilang dan penyebut 55-1= 54 maka data yang diperoleh memiliki varian yang homogen. Dari hasil analisis data diperoleh nilai yaitu $F_{\text {hitung }}=1,1<$ $F_{\text {tabel }}=1,58$ sehingga dinyatakan data yang diperoleh homogen. Uji homogenitas sebaran data secara jelasnya ditampilkan pada Tabel 5.

Tabel 5. Perhitungan Uji Homogenitas Sebaran Data

\begin{tabular}{cccccc}
\hline Sampel & Varian & $(\mathbf{d k})$ & $\mathbf{F}_{\text {hitung }}$ & $\mathbf{F}_{\text {tabel }}$ & Keterangan \\
\hline Laki-laki & 143,81 & $55-1=44$ & \multirow{2}{*}{1,1} & 1,58 & Homogen \\
Perempuan & 143,68 & $55-1=44$ & & 1,58 & Homogen \\
\hline
\end{tabular}

Pengujian hipotesis menggunakan uji-t dilakukan setelah data diperoleh berdistribusi normal dan memiliki varian yang homogen. Hipotesis yang diujikan pada penelitian ini yaitu $\mathrm{H}_{0}$. Perhitungan hipotesis dengan uji-t dilakukan menggunakan uji-t separated jika $t$ hitung $>t$ tabel maka dinyatakan $\mathrm{H}_{0}$ ditolak sedangkan apabila $\mathrm{t}$ hitung $\leq \mathrm{t}$ tabel maka $\mathrm{H}_{0}$ diterima pada taraf signifikan $5 \%$ dan db $55+55-2=108$. Dari hasil analisis diperoleh $t$ hitung $=2,41>t$ tabel $=$ 1,98 maka dinyatakan $\mathrm{H}_{0}$ ditolak. Sehingga dapat disimpulkan bahwa terdapat perbedaan yang signifikan $A Q$ antara siswa laki-laki dan perempuan kelas VI SD Gugus 1 Blahbatuh Gianyar Tahun Ajaran 2020/2021. Analisis uji-t secara jelasnya ditampilkan pada Tabel 6.

Tabel 6. Perhitungan Uji Hipotesis

\begin{tabular}{llcccccc}
\hline Sampel & Rerata & $\mathbf{S}^{2}$ & $\mathbf{N}$ & $\mathbf{( d k )}$ & $\mathbf{t}_{\text {hitung }}$ & $\mathbf{t}_{\text {tabel }}$ & Keterangan \\
\hline Siswa Laki-laki & 96,16 & 143,81 & 55 & \multirow{2}{*}{108} & \multirow{2}{*}{2,47} & \multirow{2}{*}{1,98} & \multirow{2}{*}{$\mathrm{H}_{0}$ ditolak } \\
Siswa Perempuan & 101,80 & 143,68 & 55 & & & & \\
\hline
\end{tabular}

Didasarkan pada hasil analisis data melalui perolehan penyebaran angket kemudian dianalisis dengan menggunakan analisis statistik deskriptif dan statistik inferensial, membuktikan bahwa terdapat perbedaan yang signifikan $A Q$ antara siswa laki-laki dan perempuan kelas VI SD Gugus 1 Blahbatuh Gianyar Tahun Ajaran 2020/2021. Hasil temuan pada penelitian ini yaitu rerata $A Q$ siswa perempuan lebih tinggi dibanding $A Q$ siswa lakilaki. Hal ini didasarkan pada perolehan uji statistik deskriptif yaitu rata-rata $A Q$ siswa laki-laki 
sebesar 96,16 maka dapat dikategorikan bahwa $A Q$ siswa laki-laki digolongkan pada rentang 88 - 104 dengan kategori tinggi. Sedangkan rata-rata $A Q$ siswa perempuan sebesar 101,8 maka dikategorikan bahwa $A Q$ siswa perempuan digolongkan pada rentang 88 - 104 dengan kategori tinggi. Sehingga data $A Q$ yang diperoleh melalui analisis statistik deskriptif yaitu siswa laki-laki dan perempuan memiliki rata-rata yang berbeda. Rata-rata siswa perempuan lebih besar dibanding laki-laki sehingga dinyatakan $\mathrm{AQ}$ yang dimiliki siswa perempuan secara deskriptif lebih tinggi dibandingkan siswa laki-laki. Serta temuan yang dilihat dari perolehan uji statistik inferensial dengan menggunakan analisis uji-t separated diperoleh $t$ hitung $=2,41>t$ tabel $=1,98$ yang menyatakan $A Q$ siswa laki-laki dan perempuan berbeda secara signifikan.

Kelebihan hasil temuan penelitian ini dinyatakan bahwa $A Q$ yang dimiliki oleh seseorang berbeda ditinjau dari jenis kelamin namun dipengaruhi pula dengan faktor lain seperti usia yang menyebabkan ketahanan laki-laki maupun dalam menghadapi suatu permasalahan berbeda. Laki-laki secara umum jika dilihat dari faktor usia, laki-laki dewasa memiliki rasa tanggung jawab lebih tinggi dibandingkan perempuan namun laki-laki pada usia anak-anak hingga remaja cenderung tidak ingin tahu mengenai permasalahan dari diri sendiri maupun orang lain (Wahid \& Rafah, 2017; Yoga, 2016). Sehingga dalam menghadapi permasalahan laki-laki dengan berusia diatas 30 tahun cenderung akan memiliki bertahan menghadapi permasalahan dalam kehidupan (Wahid \& Rafah, 2017). Hal ini diperkuat dengan pernyataan bahwa laki-laki secara umum lebih rasional, keras, jantan serta sebagai pelindung walaupun sebenarnya sifat yang dimiliki laki-laki tersebut merupakan sifat yang dilihat dari luar sedangkan perempuan secara umum mudah sedih, lemah lembut dan memiliki hati yang mudah tersentuh, sehingga saat mengatasi permasalahan yang dihadapi laki-laki lebih tenang dibandingkan perempuan, namun sesungguhnya perempuan lebih berusaha untuk mengatasi permasalahan-permasalahan yang dihadapi dibandingkan lakilaki.

$A Q$ yang dimiliki seseorang berdampak bagi aktivitas yang dijalankan dalam kehidupan sehari-hari khususnya pada proses pembelajaran karena $A Q$ berpengaruh positif terhadap motivasi belajar siswa (Sofyani \& Susanto, 2019). Semakin tinggi AQ yang dimiliki seseorang semakin berdampak positif bagi kegiatan yang dilakukan (Leonard, \& Amanah, 2014; Yoga, 2016). Pernyataan tersebut sama halnya dengan semakin tinggi AQ yang dimiliki siswa maka semakin berdampak positif terhadap proses pembelajaran yang dilaksanakan oleh siswa di sekolah. $A Q$ yang dimiliki oleh siswa tidak melekat dari diri siswa sendiri sejak lahir namun $A Q$ yang dimiliki dapat dikembangkan agar meminimalisir hal yang bersifat negatif terutama bagi siswa dalam proses pembelajaran. Setiap orang memiliki tiga tipe $A Q$ yang berbeda-beda diantaranya tipe quitter, camper, dan climber.

Pengembangan $A Q$ yang dimiliki oleh seseorang dilakukan dengan cara memahami kebutuhan diri dan mengetahui $A Q$ tergolong tipe bagaimana sehingga mampu mengembangkan $A Q$ yang dimiliki sesuai kebutuhan (Diana, 2018; Hidayat et al., 2018). Orang tua sebagai teladan dan model untuk menumbuh kembangkan serta membangkitkan daya juang anak. Yoga (2016) mengemukakan bahwa beberapa hal yang dapat dilakukan untuk mengembangkan $A Q$ yaitu; 1) memusatkan perhatian tentang tujuan hidup; 2) mengevaluasi setiap perkembangan diri; 3) melakukan kegiatan-kegiatan yang bermakna; 4) menunjukkan sikap positif; 5) menunjukan semangat; dan 6) memberikan diri kesempatan mengapresiasi diri sendiri. Pengembangan AQ yang dimiliki oleh seseorang khususnya bagi siswa hendaknya ditanamkan oleh sejak dini. Hal ini bertujuan untuk memepermudah pembentukan kebiasan anak yang berdampak positif bagi kegiatan yang dilaksanakan. Sebagai seorang guru hendaknya mampu memilih metode, model, strategi serta media yang tepat dalam proses pembelajaran untuk meningkat $A Q$ yang dimiliki oleh siswa.

Berdasarkan temuan pertama, penelitian ini sejalan dengan penelitian relevan yang dilakukan oleh $\mathrm{MZ}$ et al., (2017) mengenai $\mathrm{AQ}$ yang ditinjau dari jenis kelamin menyatakan bahwa $A Q$ antara laki-laki dan perempuan berpengaruh terhadap jenis kelamin dibuktikan secara deskriptif $A Q$ laki-laki dan perempuan berbeda dengan perolehan rata-rata $A Q$ lakilaki yaitu 159,39 sedangkan rata-rata $A Q$ perempuan yaitu 98,89 . Penelitian yang dilakukan 
oleh Hanum (2018) menunjukkan secara statistika terdapat perbedaan yang signifikan AQ ditinjau dari jenis kelamin antara mahasiswa laki-laki dan perempuan. Penelitian ini juga diperkuat dengan penelitian yang dilakukan oleh Wicaksana, Mardiyana, \& Usodo (2016) bahwa model pembelajaran PBL mampu menstimulus $A Q$ yang dimiliki siswa sehingga memperoleh hasil belajar siswa lebih meningkat dibanding model discovery learning dalam meningkatkan hasil belajar matematika siswa. Maka dari hal tersebut, penelitian ini terimplikasi sebagai tambahan informasi mengenai pengembangan $A Q$ yang dimiliki siswa khususnya pada jenjang sekolah dasar sehingga membantu memberikan dampak positif terhadap hasil belajar siswa di sekolah.

\section{Simpulan}

Terdapat perbedaan yang signifikan $A Q$ antara siswa laki-laki dan perempuan kelas VI SD Gugus 1 Blahbatuh Gianyar Tahun Ajaran 2020/2021. Siswa laki-laki dan perempuan memiliki rata-rata yang berbeda, rata-rata siswa perempuan lebih besar dibanding laki-laki. Dapat disimpulkan bahwa $A Q$ yang dimiliki siswa perempuan secara deskriptif lebih tinggi dibandingkan siswa laki-laki.

\section{Daftar Pustaka}

Amir, Z., Risnawati, R., Kurniati, A., \& Prahmana, R. C. I. (2017). Adversity Quotient in Mathematics Learning (Quantitative Study on Students Boarding School in Pekanbaru). International Journal on Emerging Mathematics Education, 1(2), 169. https://doi.org/10.12928/ijeme.v1i2.5780

Amory, J. D. S. (2019). Peranan Gender Perempuan Dalam Pembangunan Di Sulawesi Barat Tahun 2016-2018. Jurnal IImiah Ekonomi Pembangunan, 1(1), 1-15. Retrieved from https://stiemmamuju.e-journal.id/GJIEP/article/view/8

Artaria, M. D. (2016). Dasar Biologis Variasi Jenis Kelamin, Gender, dan Orientasi Seksual. Jurnal Biokultur, 5(1), 157-165.

Baharun, H., \& Adhimah, S. (2017). Adversity Quotient: Complementary Intelligence In Establishing Mental Endurance Santri In Pesantren. Jurnal IImiah Islam Futura, 9(1), 128-143. https://doi.org/http://dx.doi.org/10.22373/jiif.v19i1.3502

Darmadi. (2015). Peran, Kompetensi, Dan Tanggung Jawab Menjadi Guru Profesional. Jurnal Pendidikan, 13(1), 161-174. https://doi.org/http://dx.doi.org/10.31571/edukasi.v13i2.113

Darwin, C. (2019). Origin Of Spacies. Temanggung, Jawa tengah: Desa Pustaka Indonesia.

Diana, N. (2018). Mengembangkan Kemampuan Berpikir Kreatif dan Berpikir Logis Mahasiswa dengan Adversity Quotient dalam Pemecahan Masalah. Jurnal Seminar Nasional Matematika Dan Pendidikan Matematika, 2(1), 101-112. Retrieved from https://www.fkip-unswagati.ac.id/ejournal/index.php/snmpm/article/view/377

Evaliana, Y. (2015). Pengaruh Efikasi Diri Dan Lingkungan Keluarga Terhadap Minat Berwirausaha Siswa. Jurnal Pendidikan Bisnis \& Menajemen, 1(1), 61-70. Retrieved from http://journal2.um.ac.id/index.php/jpbm/article/view/1666\#: :text=Hasil penelitian menunjukkan bahwa efikasi,yang mempengaruhi minat berwirausaha siswa.

Fadhilah, N. dkk. (2020). Hubungan Antara Daya Ketahanmalangan Dan Minat Belajar Dengan Hasil Belajar Matematika Siswa. Jurnal Pendidikan Dasar, 12(1), 37-47. https://doi.org/https://doi.org/10.17509/eh.v12i1.17687

Farida, L. (2018). The Influence Of Application Argument Driven Inquiry Model To Junior High School Studen't Argumenttion Skills Based On Difference Of Gender. Journal of Physics and Science Learning, 2(3), 25-36. 
Firmanti, P. (2017). Penalaran Siswa Laki-Laki dan Perempuan Dalam Proses Pembelajaran Matematika. Journal of Gender Studies, 2(1), 73-85. https://doi.org/http://dx.doi.org/10.30983/jh.v1i2.220

Fitriyadi, H. (2013). Integrasi Teknologi Informasi Komunikasi Dalam Pendidikan: Potensi Manfaat, Masyarakat Berbasis Pengetahuan, Pendidikan Nilai, Strategi Implementasi Dan Pengembangan Professional. Jurnal Pendidikan Teknologi Dan Kejuruan, 21(3). https://doi.org/https://doi.org/10.21831/jptk.v21i3.3255

Hanum, L. (2018). Differences in Student Adversity Intelligence by Gender. Journal for Educational, Social, Political \& Cultural Studie, 1(2), 115-128. https://doi.org/https://doi.org/10.2121/.v1i2.1110

Hidayat, W., \& Sariningsih, R. (2018). Kemampuan Pemecahan Masalah Matematis dan Adversity Quotient Siswa SMP Melalui Pembelajaran Open Ended. Jurnal Nasional Pendidikan Nasional, 2(1), 109-118. https://doi.org/http://dx.doi.org/10.33603/jnpm.v2i1.1027

Hidayat, W., Herdiman, I., Aripin, U., Yuliani, A., \& Maya, R. (2018). Adversity Quotient (AQ) dan Penalaran Kreatif Matematis Mahasiswa Calon Guru. Jurnal Elemen, 4(2), 230 242. https://doi.org/10.29408/jel.v4i2.701

Idzhar, A. (2016). Peranan Guru Dalam Meningkatkan Motivasi Belajar Siswa. Jurnal Office, 2(2), 222-228. https://doi.org/https://doi.org/10.26858/jo.v2i2.2956

Irfan, A. dkk. (2018). Profil Pemecahan Masalah Pecahan Siswa Sdberdasarkan Adversity Quotient. Jurnal Program Studi Pendidikan Matematika, 4(2), 1-9.

Jayantika, I. G. A. N. T. (2018). Analisis Kontribusi Kuriositas, Ketahanmalangan Dan Kemampuan Algoritmik Terhadap Hasil Belajar Mahasiswa. Jurnal Pendidikan Matematika, 19(2), 1-12. https://doi.org/http://doi.org/10.5281/zenodo.1470953

Kadi, T., \& Awwaliyah, R. (2017). Inovasi Pendidikan: Upaya Penyelesaian Problematika Pendidikan Di Indonesia. Jurnal Islam Nusantara, 1(2), 144-155. https://doi.org/10.33852/jurnalin.v1i2.32

Kauniyah, H. A. (2016). Hubungan Kebiasaan Belajar Dengan Hasil Belajar Siswa Kelas IV SD Se-Gugus II Piyungan. 8. Jurnal Pendidikan Guru Sekolah Dasar. Retrieved from http://journal.student.uny.ac.id/ojs/ojs/index.php/pgsd/article/viewFile/4924/4586

Leonard, \& Amanah, N. (2014). Pengaruh Adversity Quotient (AQ) dan Kemampuan Berfikir Kritis Terhadap Prestasi Belajar Matematika. Jurnal Perspektif IImu Pendidikan, 28(1), 55-64. https://doi.org/https://doi.org/10.21009/PIP.281.7

Manurung, A. K. R. dkk. (2021). Permainan Outdoor dalam Membentuk Kemampuan Ketahanmalangan pada Anak Usia Dini. Jurnal Pendidikan Anak Usia Dini, 5(2), 1807-1814. https://doi.org/versitas Negeri Jakarta DOI: 10.31004/obsesi.v5i2.1030

Novilita, H., \& Suharnan, S. (2013). Konsep Diri Adversity Quotient Dan Kemandirian Belajar Siswa. Jurnal Psikologi Tabularasa, 8(1), 619-632. Retrieved from http://jurnal.unmer.ac.id/index.php/jpt/article/view/218

Nur, A. S., \& Palabo, M. (2018). Profil Kemampuan Pemecahan Masalah Matematika Siswa Ditinjau dari Perbedaan Gaya Kognitif dan Gender. Jurnal Matematika KreatifInovatif, 9(2), 139-148. https://doi.org/https://doi.org/10.15294/kreano.v9i2.15067

Parantika, I. W. A. (2020). Differences in Academic Procrastination Attitude Between Fifth Grade Male and Female Students. Journal of Psychology and Instruction, 4(1), 10 15. https://doi.org/http://dx.doi.org/10.23887/jpai.v4i1.24451

Putra, M. R. G. dkk. (2016). Hubungan Motivasi Berprestasi Dengan Adversity Quotient Warga Binaan Remaja Di LPKA Kelas II Sukamiskin Bandung. Jurnal Pendidikan 
Dan Keperawatan, 2(1), 53-61. https://doi.org/https://doi.org/10.17509/jpki.v2i1.2853

Ristiana, M. G. dkk. (2020). Adversity quotient and logical thinking skills of prospective primary school teachers. Journal of Physics: Conference Series, 1(1), 1-8. https://doi.org/:10.1088/1742-6596/1657/1/012002

Santrock, J. W. (2009). Remaja. Jakarta: Erlangga.

Sibuea, F. L., \& Andy, S. (2017). Pemetaan Siswa Berprestasi Menggunakan Metode KMeans Clustering. Jurnal Teknologi Dan Sistem Informasi, 4(1), 85-92. https://doi.org/https://doi.org/10.33330/jurteksi.v4i1.28

Sofyani, N., \& Susanto, R. (2019). Analisis Keterkaitan Kecerdasan Emosional (Emotional Quotient)Dan Ketahanmalangan (Adversity Quotient) Dalam Pembentukan Motivasi Belajar Siswa Kelas Va Di Sekolah Dasar Negerijelambar Baru 01. Jurnal Dinamika Sekolah Dasar, 1(1), 1-13. Retrieved from https://journal.pgsdfipunj.com/index.php/dinamika/article/view/96

Stoltz, P. G. (2000). Adversity Quotient Mengubah Hambatan Menjadi Peluang. Jakarta: PT Gresindo.

Stoltz, P. G. (2007). Adversity Quotient. Jakarta: PT Gresindo.

Suhendri, H. (2018). Peranan Ketahanmalangan dan Kreativitas Dalam Pembelajaran Matematika. Jurnal Pendidikan Dan Pemberdayaan Masyarakat, 11(1), 31-40. https://doi.org/http://dx.doi.org/10.30870/jppm.v11i1.2982

Sukardi. (2008). Metode Penelitian Pendidikan. Jakarta: PT. Bumi Angkasa.

Wahid; Rafah. (2017). Rasa Tanggung Jawab Anak Sulung Di Kota Makassar. Jurnal Talenta, 2(2), 1-9. https://doi.org/https://doi.org/10.26858/talenta.v2i2.13202

Wicaksana, H., Mardiyana, \& Usodo, B. (2016). Eksperimentasi Model Pembelajaran Problem Based Learning (PBL) dan Discovery Learning (DL) dengan Pendekatan Saintifik pada Materi Himpunan Ditinjau dari Adversity Quotient (AQ) Siswa. Jurnal Elektronik Pembelajaran Matematika, 4(3), 258-269. Retrieved from https://jurnal.fkip.uns.ac.id/index.php/s2math/article/view/8574

Yoga, M. (2016). Adversity Quotient Agar Anak Tidak Mudah Menyerah. Solo: Tinta Medina.

Yusup, F. (2018). Uji Validitas dan Reliabilitas Instrumen Penelitian Kuantitatif. Jurnal Tarbiyah: Jurnal Ilmiah Kependidikan, 7(1), 17-23. https://doi.org/https://dx.doi.org/10.18592/tarbiyah.v7i1.2100 